\title{
Processes determining the marine alkalinity and calcium carbonate saturation state distributions
}

\author{
B. R. Carter $^{1}$, J. R. Toggweiler ${ }^{2}$, R. M. Key ${ }^{1}$, and J. L. Sarmiento ${ }^{1}$ \\ ${ }^{1}$ Atmospheric and Oceanic Sciences Program, Princeton University, Princeton, NJ, USA \\ ${ }^{2}$ Geophysical Fluid Dynamics Laboratory, National Oceanic and Atmospheric Administration, P.O. Box 308, \\ Princeton NJ, 08542, USA
}

Correspondence to: B. R. Carter (brcarter@princeton.edu)

Received: 1 July 2014 - Published in Biogeosciences Discuss.: 21 July 2014

Revised: 21 November 2014 - Accepted: 21 November 2014 - Published: 19 December 2014

\begin{abstract}
We introduce a composite tracer for the marine system, $\mathrm{Alk}^{*}$, that has a global distribution primarily determined by $\mathrm{CaCO}_{3}$ precipitation and dissolution. $\mathrm{Alk}^{*}$ is also affected by riverine alkalinity from dissolved terrestrial carbonate minerals. We estimate that the Arctic receives approximately twice the riverine alkalinity per unit area as the Atlantic, and 8 times that of the other oceans. Riverine inputs broadly elevate Alk* in the Arctic surface and particularly near river mouths. Strong net carbonate precipitation results in low Alk* in subtropical gyres, especially in the Indian and Atlantic oceans. Upwelling of dissolved $\mathrm{CaCO}_{3}$-rich deep water elevates North Pacific and Southern Ocean Alk*. We use the Alk* distribution to estimate the variability of the calcite saturation state resulting from $\mathrm{CaCO}_{3}$ cycling and other processes. We show that regional differences in surface calcite saturation state are due primarily to the effect of temperature differences on $\mathrm{CO}_{2}$ solubility and, to a lesser extent, differences in freshwater content and air-sea disequilibria. The variations in net calcium carbonate cycling revealed by $\mathrm{Alk}^{*}$ play a comparatively minor role in determining the calcium carbonate saturation state.
\end{abstract}

\section{Introduction}

Our goal is to use high-quality total alkalinity $\left(A_{\mathrm{T}}\right)$ observations to examine the effects of calcium carbonate cycling on marine $A_{\mathrm{T}}$ and calcium carbonate saturation states. This study is motivated in part by ocean acidification. With marine calcite saturation states decreasing due to anthropogenic carbon uptake (Orr et al., 2005), it is important to understand the degree to which carbonate cycling impacts the calcium carbonate saturation state.

Carbonate saturation state is a measure of how supersaturated seawater is with respect to a given mineral form of calcium carbonate. It is expressed for calcite as the ratio $\Omega_{C}$ between the product of $\mathrm{Ca}^{2+}$ and $\mathrm{CO}_{3}^{2-}$ ion concentrations and the calcite thermodynamic equilibrium solubility product. Values of $\Omega_{\mathrm{C}}$ greater than 1 indicate calcite precipitation is favored thermodynamically over calcite dissolution, and the reverse is true for values less than 1 .

Marine calcium carbonate cycling includes both internal and external calcium carbonate sources and sinks. Internal cycling refers to net formation of $67-300 \mathrm{~T}$ mol $A_{\mathrm{T}} \mathrm{yr}^{-1}$ worth of calcium carbonate in the surface ocean (Berelson et al., 2007) and net dissolution of most of this calcium carbonate at depth. External marine carbonate cycling refers to inputs of carbonate minerals dissolved in rivers, sediment pore waters, hydrothermal vent fluids, and submarine groundwater discharge, as well as to loss due to biogenic carbonate mineral burial and authigenic mineralization in sediments. Rivers add $33 \mathrm{~T} \mathrm{~mol} A_{\mathrm{T}} \mathrm{yr}^{-1}$ worth of dissolved bicarbonate to the ocean (Cai et al., 2008). Wolery and Sleep (1988) estimate that hydrothermal vents add an additional $6.6 \mathrm{~T} \mathrm{~mol}$ $A_{\mathrm{T}} \mathrm{yr}^{-1}$, though deVilliers (1998) argues the hydrothermal contribution may be as high as $30 \mathrm{~T} \mathrm{~mol} A_{\mathrm{T}} \mathrm{yr}^{-1}$. Submarine groundwater discharge is poorly constrained, but it is thought to exceed riverine inputs in some areas (Moore, 2010).

We investigate calcium carbonate cycling using the global AT distribution in a dataset we created by merging the Global Data Analysis Project (GLODAP), Carbon in the North Atlantic (CARINA), and Pacific Ocean Interior 
Carbon (PACIFICA) discrete data products (Key et al., 2004, 2010; Velo et al., 2009; Suzuki et al., 2013). We have combined and gridded these data products using methods detailed in Supplement document SA. We use our gridded data set in our calculations to limit sampling biases and to enable us to make volume-weighted mean property estimates.

Dickson (1981) defines total alkalinity as the concentration excess "of proton acceptors formed from weak acids $(\mathrm{pK} \leq 4.5)$ relative to proton donors (weak bases with $\mathrm{pK}>$ 4.5 )" at a reference temperature, pressure, and ionic strength. $A_{\mathrm{T}}$ can be thought of as a measure of how well-buffered seawater is against changes in $\mathrm{pH}$. This operational definition gives $A_{\mathrm{T}}$ (expressed in mol kg ${ }^{-1}$ ) several properties that make it an especially useful carbonate system parameter for examining carbonate cycling:

1. It mixes conservatively

2. ... and is therefore diluted and concentrated linearly by evaporation and precipitation.

3. It responds in predictable ways to calcium carbonate cycling

4. ... as well as organic matter formation and remineralization.

5. It is not changed by air-sea exchange of heat or carbon dioxide.

6. It is, however, affected by anaerobic redox reactions (Chen, 2002).

We are primarily interested in calcium carbonate cycling, item 3 in our list. In Sect. 2 of this paper we therefore define a tracer we call $\mathrm{Alk}^{*}$ that removes the majority of the influences of organic matter cycling (item 4), freshwater cycling (item 2), and non-sedimentary anaerobic redox reactions (item 6) while still mixing conservatively, remaining insensitive to gas exchange, and responding to calcium carbonate cycling. In Sect. 3 we discuss processes that govern the Alk* distribution globally, by ocean basin, and regionally. In Sect. 4 we define a metric to quantify the influence of various processes on the marine calcite saturation state. We use this metric with our gridded data set and $\mathrm{Alk}^{*}$ to determine the relative importance of the various controls on calcite saturation state in the ocean and at the ocean surface. We summarize our findings in Sect. 5.

\section{The Alk* tracer}

In defining $\mathrm{Alk}^{*}$, we take advantage of the potential alkalinity (Brewer et al., 1975) concept to remove the majority of the influence of organic matter cycling and denitrification, and use a specific salinity normalization scheme (Robbins, 2001) to remove the influence of freshwater cycling. We detail the $\mathrm{Alk}^{*}$ definition and the reasoning behind it in this section.
The influence of organic matter cycling on $A_{\mathrm{T}}$ is due primarily to the biologically driven marine nitrogen cycle. $\mathrm{Ni}$ trate uptake for anaerobic denitrification and the production of amino acids occurs in a $\sim 1: 1$ mole ratio with the release of molecules that increase $A_{\mathrm{T}}$ (Chen, 2002). Similarly, nitrate from fixation of nitrogen gas and remineralization of amino nitrogen is released in a $1: 1$ mole ratio with acids that titrate away $A_{\mathrm{T}}$ (Wolf-Gladrow et al., 2007). This observation led Brewer et al. (1975) to propose the idea of "potential alkalinity" as the sum of $A_{\mathrm{T}}$ and nitrate, with the aim of creating a tracer that responds to the cycling of calcium carbonates without changing in response to organic matter cycling. Feely et al. (2002) since used a variant that relies on the empirical relationship between dissolved calcium concentrations, $A_{\mathrm{T}}$, and nitrate determined by Kanamori and Ikegami (1982). This variant has the advantage of implicitly accounting for the $A_{\mathrm{T}}$ changes created by the exchange of numerous other components of marine organic matter besides nitrate (e.g., sulfate and phosphate). We thus use the ratio found by Kanamori and Ikegami (1982) to define potential alkalinity $\left(A_{\mathrm{T}}\right)$.

$A_{\mathrm{P}}=A_{\mathrm{T}}+1.26 \times\left[\mathrm{NO}_{3}^{-}\right]$

While the empirical Kanamori and Ikegami (1982) ratio of 1.26 may be specific to the elemental ratios of the North $\mathrm{Pa}$ cific, Wolf-Gladrow et al. (2007) provide a theoretical derivation from Redfield ratios and obtain a similar value of 1.36.

The sensitivity of the $A_{\mathrm{T}}$ distribution to freshwater cycling is due primarily to the dilution or concentration of the large background $A_{\mathrm{T}}$ fraction that does not participate in carbonate cycling on timescales of ocean mixing. This background fraction behaves conservatively, so we call it conservative potential alkalinity $\left(A_{\mathrm{P}}^{\mathrm{C}}\right)$ and estimate it directly from salinity as

$A_{\mathrm{P}}^{\mathrm{C}} \equiv S \frac{\overline{A_{\mathrm{P}}}}{\bar{S}}$.

Here, terms with a bar are reference values chosen as the mean value for those properties in the top $20 \mathrm{~m}$ of the ocean. We obtain a volume-weighted surface $\overline{A_{\mathrm{P}}}\left(2305 \mu \mathrm{mol} \mathrm{kg}{ }^{-1}\right)$ to $\bar{S}$ (34.71) ratio of $66.40 \mu \mathrm{mol} \mathrm{kg}{ }^{-1}$ from our gridded data set. The mean surface values are chosen in an effort to best capture the impact of freshwater cycling where precipitation and evaporation occur.

Robbins (2001) showed that subtracting an estimate of the conservative portion of a tracer, such as $A_{\mathrm{P}}^{\mathrm{C}}$, produces a salinity-normalized composite tracer that mixes conservatively. This scheme also retains the $2: 1$ change of $A_{\mathrm{T}}$ to dissolved inorganic carbon $\left(C_{\mathrm{T}}\right)$ with carbonate cycling. We follow this approach in our definition of Alk* In Supplement document SB we estimate this approach removes $97.5 \%$ of the influence of freshwater cycling on potential alkalinity and reduces the influence of freshwater cycling on $\mathrm{Alk}^{*}$ to less than $1 \%$ of the $\mathrm{Alk}^{*}$ variability. In Supplement document $\mathrm{SC}$ we demonstrate that $\mathrm{Alk}^{*}$ mixes conservatively, and 
we briefly contrast Alk* to traditionally normalized potential alkalinity which does not mix conservatively (Jiang et al., 2014).

In total, we define $\mathrm{Alk}^{*}$ as the deviation of potential alkalinity from $A_{\mathrm{P}}^{\mathrm{C}}$ :

$$
\begin{aligned}
\text { Alk }^{*} & \equiv A_{\mathrm{P}}-\frac{A_{\mathrm{P}}^{\mathrm{C}}}{A_{\mathrm{P}}} S \\
& \equiv A_{\mathrm{P}}-\frac{\bar{S}}{S} \\
& \equiv A_{\mathrm{P}}-66.4 \times S,
\end{aligned}
$$

where $\mathrm{Alk}^{*}$ has the same units as $A_{\mathrm{T}}\left(\mu \mathrm{mol} \mathrm{kg}{ }^{-1}\right)$. The $\mathrm{Alk}^{*}$ distribution is attributable primarily to carbonate cycling plus the small (in most places) residual variation due to freshwater cycling that is not removed by subtracting $A_{\mathrm{P}}^{\mathrm{C}}$. However, hydrothermal vent fluid and non-denitrification anaerobic redox chemistry may substantively affect alkalinity distributions in certain marine environments, and $\mathrm{Alk}^{*}$ distributions could not be attributed purely to internal and external calcium carbonate cycling in these locations.

Mean global surface Alk* is 0 by definition, and thus Alk* can have negative as well as positive values. For reference, more than $95 \%$ of our gridded $\mathrm{Alk}^{*}$ data set falls between -35 and $220 \mu \mathrm{mol} \mathrm{kg}{ }^{-1}$. Comparing gridded $\mathrm{Alk}^{*}$ to $\mathrm{Alk}^{*}$ from measurements suggests a standard disagreement of order $10 \mu \mathrm{mol} \mathrm{kg}^{-1}$. We adopt this number as an estimate of standard gridded Alk* error despite noting there are reasons to suspect that this value could be either an underestimate (correlated errors) or an overestimate (we are directly comparing instantaneous point measurements to estimates for annual averages for a grid cell).

\section{Alk* distributions}

We consider Alk* distributions globally, by ocean basin, and regionally in the context of sources and sinks of the tracer both globally and regionally. We pay special attention to riverine Alk* because it is easily identified where it accumulates near river mouths.

\subsection{Global distribution of Alk*}

Figure 1 maps surface Alk* (top 50 m) at the measurement stations. We provide this figure to show where we have viable Alk* estimates and to demonstrate that our gridded data product adequately captures the measured Alk* distribution. Figure 2 maps gridded global surface $A_{\mathrm{T}}$, salinity, Alk* and phosphate distributions and masks the regions that are lacking data in Fig. 1.

The similarity of the $A_{\mathrm{T}}$ (Fig. 2a) and salinity (Fig. 2b) distributions demonstrates the strong influence of freshwater cycling on the surface marine $A_{\mathrm{T}}$ distribution (see also Millero et al., 1998; Jiang et al., 2014). The dissimilarity between Alk* (Fig. 2c) and salinity (Fig. 2b) suggests Alk* removes the majority of this influence. The phosphate (Fig. 2d) and

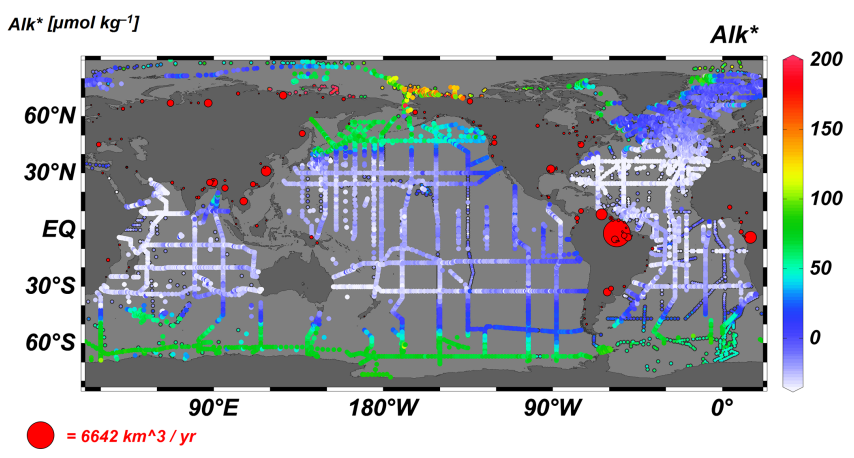

Figure 1. A map of station locations at which we use measurements to estimate $\mathrm{Alk}^{*}$ (in $\mu \mathrm{mol} \mathrm{kg}{ }^{-1}$ ). Dot color indicates surface Alk*. Points with black borders indicate either that AT was measured prior to 1992 (i.e., before reference materials were commonly used) or that no nitrate value was reported (in which case a nitrate concentration of $5 \mu \mathrm{mol} \mathrm{kg}-1$ is assumed). Red dots on land indicate the mouth locations and mean annual discharge volumes (indicated by dot size) of 200 large rivers, as given by Dai and Trenberth (2002).

Alk* (Fig. 2c) distributions are similar at the surface. They are also similar at depth: Figs. 3 and 4 show zonally averaged gridded depth sections of Alk* and phosphate. Alk* and phosphate concentrations are low in the deep Arctic Ocean (Figs. 3d, and 4d), intermediate in the deep Atlantic Ocean (Figs. 3a and 4a), and high in the deep North Pacific (Figs. 3b and $4 b$ ) and deep northern Indian (Figs. 3c and 4c) oceans. $\mathrm{Alk}^{*}$ and phosphate distributions are similar because similar processes shape them: the hard and soft tissue pumps transport $A_{\mathrm{T}}$ and phosphate, respectively, from the surface to depth. The "oldest" water therefore has the highest net phosphate and Alk* accumulation. High surface phosphate and Alk* in the Southern Ocean and North Pacific in Figs. 2, 3, and 4 are due to upwelled old, deep waters.

Several qualitative differences between $\mathrm{Alk}^{*}$ and phosphate distributions are visible in Figs. 2c, 2d, 3, and 4. Surface phosphate is low in the Bay of Bengal and high in the Arabian Sea (Fig. 2d), while the opposite is true for Alk* (Fig. 2c). Also, Alk* reaches its highest surface concentration in the Arctic (Figs. 2c and 3d) where phosphate is not greatly elevated (Figs. $2 \mathrm{~d}$ and $4 \mathrm{~d}$ ). These surface differences are due to regional riverine Alk* inputs (Sect. 3.3). Another difference is that Alk* reaches a maximum below $2000 \mathrm{~m}$ in all ocean basins except the Arctic, while phosphate maxima are above $2000 \mathrm{~m}$. We attribute the deeper Alk* maxima to deeper dissolution of calcium carbonates than organic matter remineralization. Finally, Alk* values are higher in the deep Indian Ocean than in the deep Pacific. This is likely due to elevated biogenic carbonate export along the coast of Africa and in the Arabian Sea (Sarmiento et al., 2002; Honjo et al., 2008). 

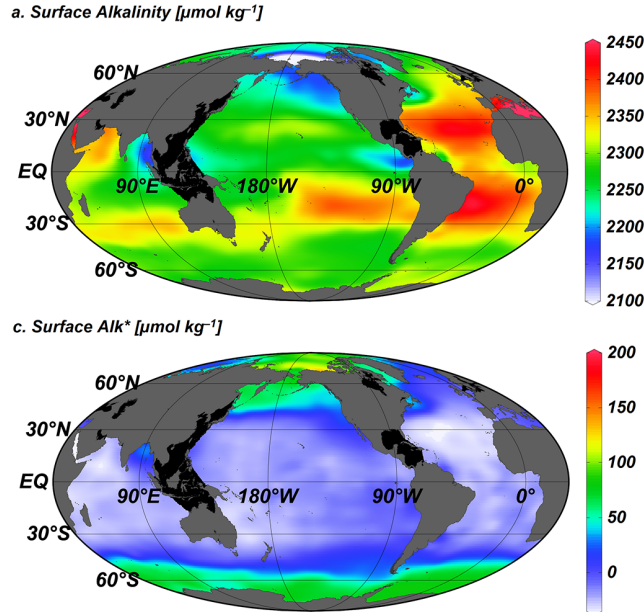

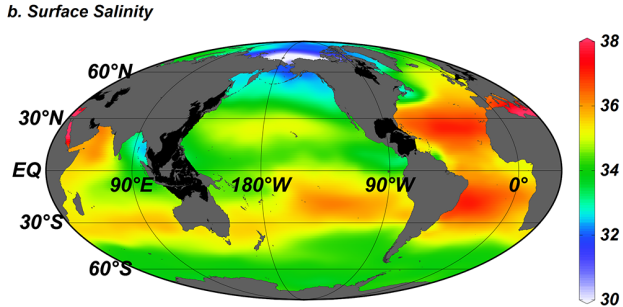

d. Surface Phosphate $\left[\mu \mathrm{mol} \mathrm{kg}^{-1}\right]$

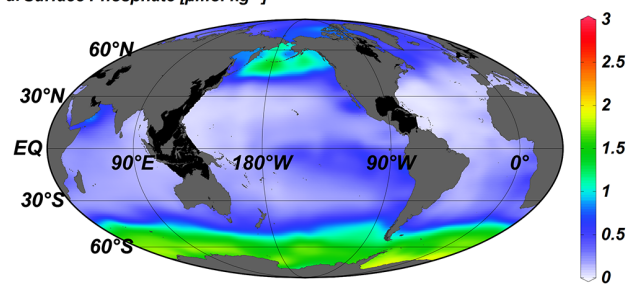

Figure 2. Global (a) total alkalinity $A_{\mathrm{T}}$, (b) salinity, (c) Alk*, and (d) phosphate distributions at the surface (10 m depth surface) from our gridded CARINA, PACIFICA, and GLODAP bottle data product detailed in Supplement document SA. Areas with exceptionally poor coverage in the data used to produce the gridded product are blacked out.
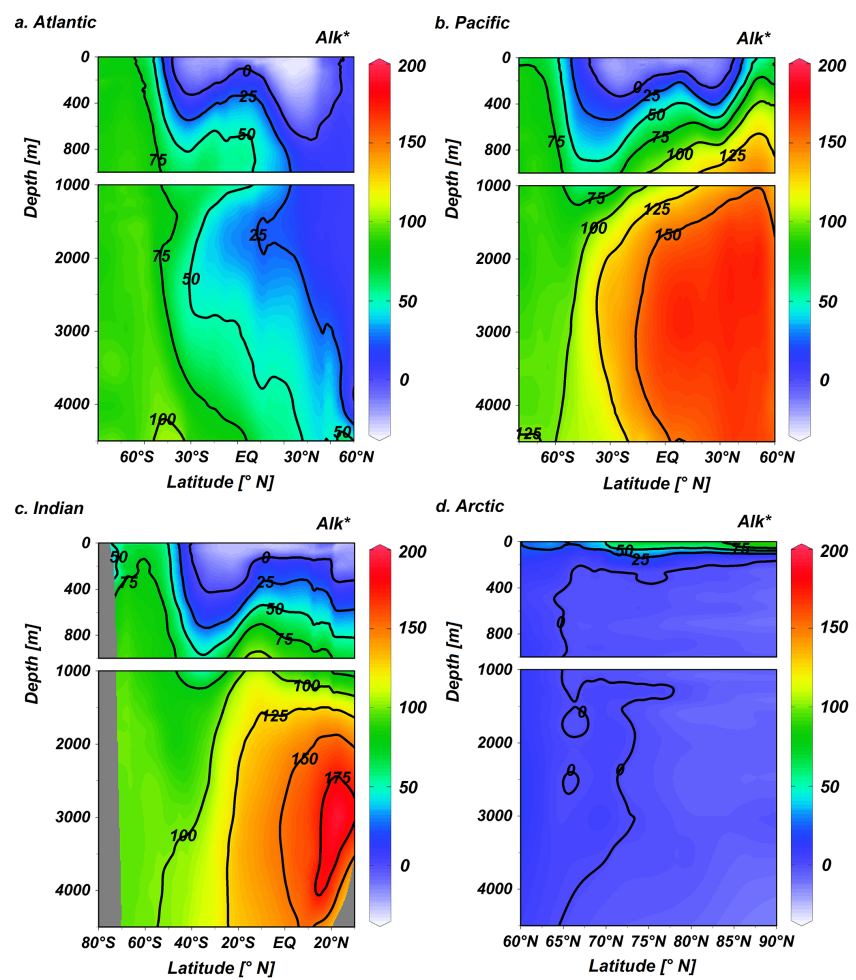

Figure 3. Zonal mean gridded $\mathrm{Alk}^{*}$ (in $\mu \mathrm{mol} \mathrm{kg}{ }^{-1}$ ) in the (a) Atlantic, (b) Pacific, (c) Indian, and (d) the Arctic oceans plotted against latitude and depth.

\section{2 $\quad$ Alk $^{*}$ by ocean basin}

In Fig. 5 we provide 2-D color histograms of discrete surface $\mathrm{Alk}^{*}$ and salinity measurements for the five major ocean basins. Figure 5 also indicates a single volume-weighted mean gridded Alk* for each basin (in writing). We attribute the decrease in $\mathrm{Alk}^{*}$ as salinity increases - especially visible in the low-salinity bins in the Arctic Ocean (Fig. 5d) to mixing between high-Alk*, low-salinity river water and low-Alk*, high-salinity open-ocean water. Net precipitation in the tropics and net evaporation in the subtropics widens the histograms across a range of salinities and alkalinities without affecting Alk* in Fig. 5a, b, and c. The Alk* elevation associated with upwelled water is most visible in Fig. 5e where Upper Circumpolar Deep Water upwelling near the Polar Front results in high-frequency (i.e., warm colored) histogram bins at high-Alk* . Similarly, the high-frequency Alk* bins in Fig. 5b with salinity between 32.5 and 33.5 are from the North Pacific Subpolar Gyre, and are due to upwelled old, high-Alk* water (cf. the $\mathrm{Si}^{*}$ tracer in Sarmiento et al., 2004). River water contributions can be most easily seen in a scattering of low-frequency (cool colored), high-Alk* as well as low-salinity bins in the Arctic Ocean.

The surface Southern Ocean has the highest Alk* followed by the Arctic and the Pacific. The Indian and Atlantic have similar and low mean Alk*. The high mean Southern Ocean Alk* is due to upwelling. The high mean Arctic surface Alk* is due to riverine input. The Atlantic and the Arctic together receive $\sim 65 \%$ of all river water (Dai and Trenberth, 2002). We construct a budget for terrestrial $A_{\mathrm{T}}$ sources to the various surface ocean basins using the following assumptions:

1. the $A_{\mathrm{T}}$ of 25 large rivers are as given by Cai et al. (2008);

2. the volume discharge rates of 200 large rivers are as given by Dai and Trenberth (2002);

3. groundwater and runoff enter each ocean in the same proportion as river water from these 200 rivers; 

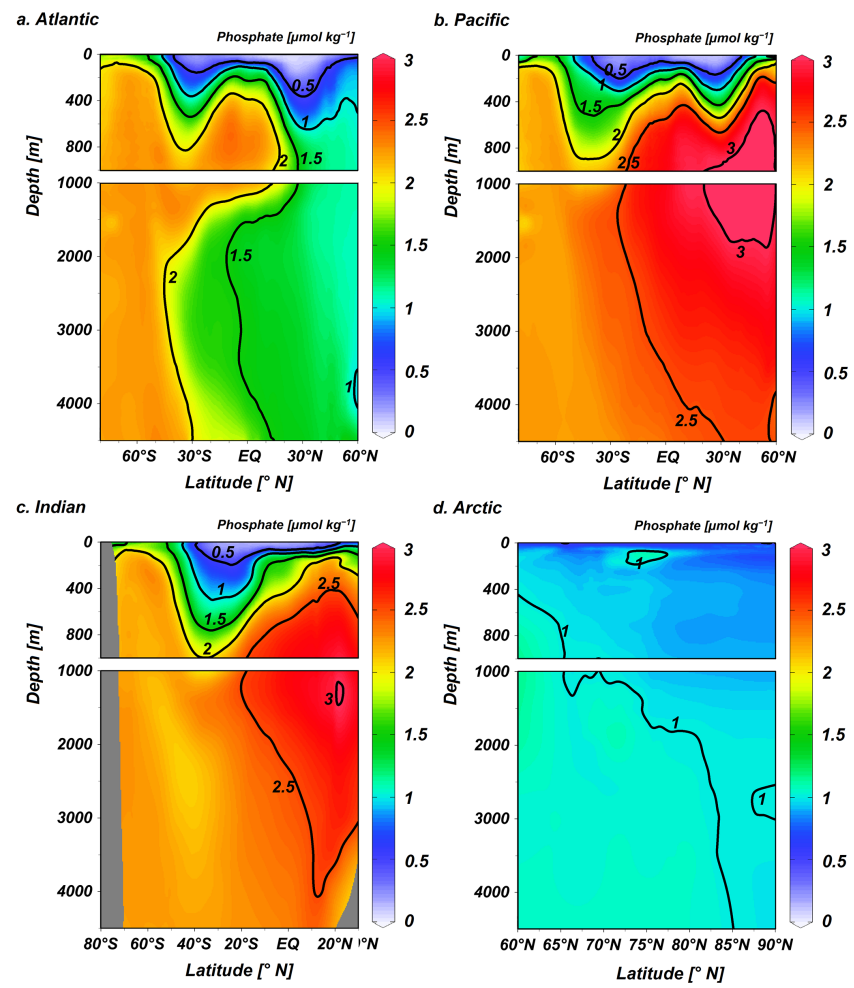

Figure 4. Zonal mean gridded phosphate (in $\mu \mathrm{mol} \mathrm{kg} \mathrm{kg}^{-1}$ ) in the (a) Atlantic, (b) Pacific, (c) Indian, and (d) the Arctic oceans plotted against latitude and depth.

4. the $A_{\mathrm{T}}$ of all water types that we do not know from assumption 1 is the $1100 \mu \mathrm{mol} \mathrm{kg}{ }^{-1}$ global mean value estimated by Cai et al. (2008);

5. $40^{\circ} \mathrm{N}$ is the boundary between the Atlantic and the Arctic, and $40^{\circ} \mathrm{S}$ is the boundary between the Southern and the Atlantic oceans (based upon the region of elevated surface phosphate in Fig. 2d).

Our detailed budget is provided as Supplement file SD. We estimate $40 \%$ of continentally derived $A_{\mathrm{T}}$ enters the Atlantic, $20 \%$ enters the Arctic, and $40 \%$ enters all remaining ocean basins. These ocean areas represent 17,5 , and $78 \%$ of the total surface ocean area in our gridded data set, respectively, so the Arctic receives approximately twice as much riverine $A_{\mathrm{T}}$ per unit area as the Atlantic, and 8 times the rest of the world ocean. The Atlantic has the lowest openocean surface Alk* value and low basin mean surface $\mathrm{Alk}^{*}$ despite the large riverine sources. The large riverine $A_{\mathrm{T}}$ input must therefore be more than balanced by strong net calcium carbonate formation. The Indian Ocean has comparably low mean surface Alk* to the Atlantic, but a smaller riverine source. Mean Alk* is higher in the Pacific than the Atlantic and Indian, even when neglecting the region north of $40^{\circ} \mathrm{N}$ as we do for the Atlantic (Alk* $=-16.5 \mu \mathrm{mol} \mathrm{kg}-1$ when omitted vs. $-22.9 \mu \mathrm{mol} \mathrm{kg} \mathrm{g}^{-1}$ for the Atlantic and $-22.2 \mu \mathrm{mol} \mathrm{kg}^{-1}$ for the Indian). The difference between the

a.

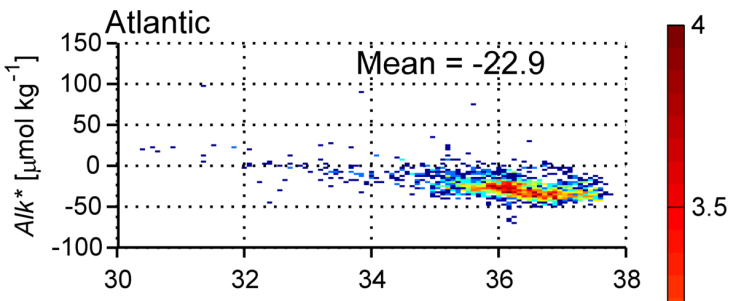

b.

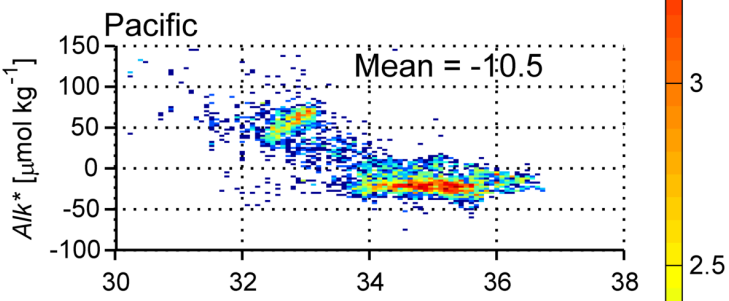

c.

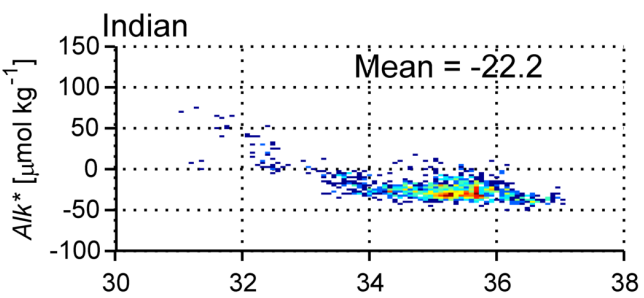

d.

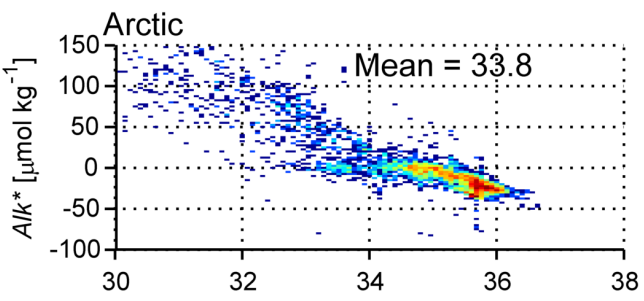

e.

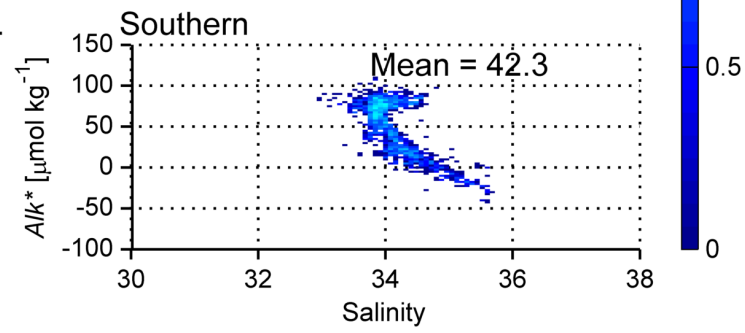

Figure 5. 2-D histograms indicating the $\log$ (base 10) of the number of measurements that fall within bins of Alk* vs. salinity with color. Data are limited to the top $50 \mathrm{~m}$ of the (a) Atlantic, (b) Pacific, (c) Indian, (d) Arctic, and (e) Southern oceans. Where basins connect, the boundary between the Atlantic and the Arctic oceans is $40^{\circ} \mathrm{N}$, between the Atlantic and the Indian it is $20^{\circ} \mathrm{E}$, between the Indian and the Pacific it is $131^{\circ} \mathrm{E}$, between the Pacific and the Atlantic it is $70^{\circ} \mathrm{W}$, and between the Southern Ocean and the other oceans it is $40^{\circ} \mathrm{S}$.

Pacific and the other basins is significant when considering the large number of grid cell Alk* values averaged ( $>6000$ in the Atlantic), and the small estimated uncertainty for each value $\left(\sim 10 \mu \mathrm{mol} \mathrm{kg}^{-1}\right)$. Considering the weak Pacific riverine input, this suggests that, relative to other ocean basins, there are either larger Alk* inputs from exchange with other 

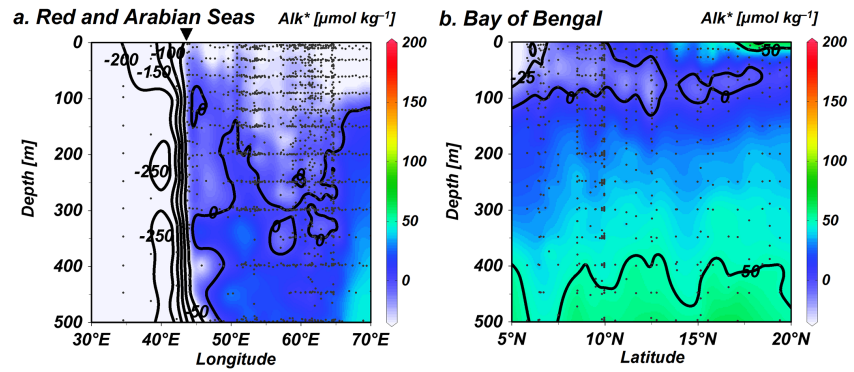

Figure 6. Alk* distributions (in $\mu \mathrm{mol} \mathrm{kg}{ }^{-1}$ ) (a) between $5^{\circ}$ and $30^{\circ} \mathrm{N}$ in the Red and Arabian seas shown against longitude, and (b) between $75^{\circ}$ and $100^{\circ} \mathrm{E}$ in the Bay of Bengal plotted against latitude. Small black dots indicate where data are present. The inverted triangle above (a) indicates the longitude of the mouth of the Red Sea.

basins and deeper waters or smaller Pacific basin mean net calcium carbonate formation.

\subsection{Riverine Alk* regionally}

For river water with negligible salinity, Alk* equals the potential alkalinity. This averages around $1100 \mu \mathrm{mol} \mathrm{kg}^{-1}$ globally (Cai et al., 2008) but is greater than $3000 \mu \mathrm{mol} \mathrm{kg}^{-1}$ for some rivers (Beldowski et al., 2010). Evidence suggests that riverine $A_{\mathrm{T}}$ is increasing due to human activities (Kaushal et al., 2013).

The most visible riverine Alk* signals are in the Arctic due to the large riverine runoff into this comparatively small basin and the confinement of this low-density riverine water to the surface (Jones et al., 2008; Yamamoto-Kawai et al., 2009; Azetsu-Scott et al., 2010). Figure 3d shows the high Arctic Alk* plume is confined to the top $\sim 200 \mathrm{~m}$. Figure 1 shows that these high Alk* values extend along the coast of Greenland and through the Labrador Sea. Alk* decreases with increasing salinity in this region (Fig. 5d) due to mixing between the fresh high-Alk* surface Arctic waters and the salty, lower-Alk* waters of the surface Atlantic. Gascard et al. (2004a, b) suggest that waters along the coast of Norway are part of the Norwegian Coastal Current and originate in the Baltic and North seas where there are also strong riverine inputs (Thomas et al., 2005).

Elevated Alk* can also be seen in the Bay of Bengal, with surface values $\sim 100 \mu \mathrm{mol} \mathrm{kg}{ }^{-1}$ higher than those in the central Indian Ocean. This bay has two high- $A_{\mathrm{T}}$ rivers that join and flow into it, the Brahmaputra $\left(A_{\mathrm{T}}=1114 \mu \mathrm{mol} \mathrm{kg}{ }^{-1}\right)$ and the Ganges $\left(A_{\mathrm{T}}=1966 \mu \mathrm{mol} \mathrm{kg}{ }^{-1}\right)$ (Cai et al., 2008). Figure $6 \mathrm{~b}$ provides provides an Alk* depth section for this region. The riverine Alk* plume can be clearly seen in the top $50 \mathrm{~m}$. No similar increase is seen in the Arabian Sea (Fig. 6a), where the Indus River $\left(1681 \mu \mathrm{mol} \mathrm{kg}{ }^{-1}\right)$ discharges only $\sim 1 / 10$ th of the combined volume of the Brahmaputra and the Ganges.

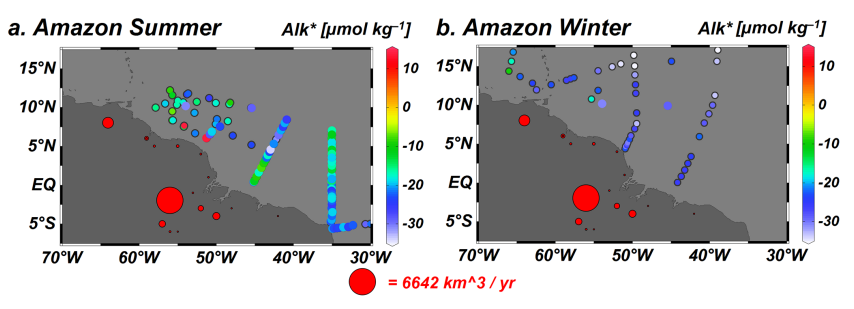

Figure 7. Alk* (in $\mu \mathrm{mol} \mathrm{kg}-1$ ) in top $50 \mathrm{~m}$ of the ocean near the Amazon River outflow plotted in color, though with a narrower color scale than is used for all other plots. Panel (a) is limited to data collected in November through January, and panel (b) is limited to measurements from May through July. Points with black borders indicate either that the AT was measured prior to 1992 (before reference materials were commonly used) or that no nitrate value was reported (in which case a nitrate concentration of $5 \mu \mathrm{mol} \mathrm{kg} \mathrm{kg}^{-1}$ is assumed). Red dots on land indicate the mouth locations and mean annual discharge volumes (indicated by dot size) of large rivers, as given by Dai and Trenberth (2002).

The Amazon River is the largest single riverine marine $A_{\mathrm{T}}$ source. This river has low $A_{\mathrm{T}}\left(369 \mu \mathrm{mol} \mathrm{kg}{ }^{-1}\right.$; Cai et al., 2008) but has the largest water discharge volume of any river, exceeding the second largest - the Congo - by a factor of $\sim 5$ (Dai and Trenberth, 2002). Consequently, the Amazon discharges approximately $50 \%$ more $A_{\mathrm{T}}$ per year than the river with the second-largest $A_{\mathrm{T}}$ discharge, the Changjiang (Cai et al., 2008). The Amazon's influence can be seen as a region of abnormally low salinity and $A_{\mathrm{T}}$ in Fig. 2a and b. Despite the high discharge volume, the influence is only barely visible as a region of elevated Alk* in Fig. 2c due to the comparatively low Amazon Alk*. However, the influence of the Amazon on Alk* can be seen in the seasonal Alk* cycle in the Amazon plume. Figure 7 provides a map of Alk* for this region scaled to show the influence of this low-Alk* river in the Northern Hemisphere (a) winter and (b) summer months. The higher Alk* found for summer months is consistent with Amazon discharge and $A_{\mathrm{T}}$ seasonality (Cooley et al., 2007) and the radium-isotope-based finding of Moore et al. (1986) that Amazon River outflow comprises $20-34 \%$ of surface water in this region in July compared to only 5-9\% in December.

\subsection{Regional abiotic carbonate cycling}

The Red Sea portion of Fig. 6a is strongly depleted in Alk* and contains the lowest single Alk* measurement in our data set, $-247 \mu \mathrm{mol} \mathrm{kg}{ }^{-1}$. The GEOSECS expedition Red Sea alkalinity measurements (Craig and Turekian, 1980) predate alkalinity reference materials (Dickson et al., 2007) but are supported by more recent measurements (Silverman et al., 2007). Like Jiang et al. (2014), we attribute low Red Sea $\mathrm{Alk}^{*}$ to exceptionally active calcium carbonate formation. Brewer and Dyrssen (1985) provide seawater chemistry measurements from the neighboring Persian Gulf that suggest 
strong calcium carbonate formation results in low $\mathrm{Alk}^{*}$ there as well $\left(<-240 \mu \mathrm{mol} \mathrm{kg} \mathrm{kg}^{-1}\right.$ along the Trucial Coast).

The Red Sea is one of the only regions where $\Omega_{C}$ is sufficiently high for abiotic carbonate precipitation to significantly contribute to overall carbonate precipitation (Milliman et al., 1969; Silverman et al., 2007). Notably, saturation state remains high at depth in the Red Sea (see Sect. 4.2). In this region, biogenic aragonitic corals and pteropod shells are progressively removed with depth in sediments, and pores left behind are filled in with high-magnesium calcite cement (Gevirtz and Friedman, 1966; Almogi-Labin et al., 1986). We hypothesize biogenic carbonates are dissolved by $\mathrm{CO}_{2}$ from sedimentary organic matter remineralization, as occurs elsewhere (e.g., Hales and Emerson, 1997; Hales, 2003; Boudreau, 2013), and that high deep Red Sea $\Omega_{\mathrm{C}}$ leads to abiotic re-calcification in sediment pores. Morse et al. (2006) find that synthetic high-magnesium calcite - unlike biogenic high-magnesium calcite - is less soluble than aragonite, so this substitution is favored thermodynamically if the abiotic mineral forms similarly to the synthetic mineral.

Calcium carbonate has recently been found as metastable ikaite (a hydrated mineral with the formula $\mathrm{CaCO}_{3} \times 6 \mathrm{H}_{2} \mathrm{O}$ ) in natural sea ice (Dieckmann et al., 2008). Ikaite cycling provides a competing explanation for the high Arctic surface $\mathrm{Alk}^{*}$ values if high- $A_{\mathrm{T}}$, low-salinity, ikaite-rich ice melt becomes separated from low- $A_{\mathrm{T}}$, high-salinity rejected brines. However, riverine $A_{\mathrm{T}}$ inputs better explain the magnitude of the feature: the $\sim 5 \mathrm{mg}$ ikaite $\mathrm{L}^{-1}$ sea ice that Dieckmann et al. (2008) found in the Antarctic could only enrich $A_{\mathrm{T}}$ of the surface $100 \mathrm{~m}$ by $\sim 1 \mu \mathrm{mol} \mathrm{kg}{ }^{-1}$ for each meter of ice melted, and Arctic surface $100 \mathrm{~m} \mathrm{Alk} *$ is elevated by $59 \mu \mathrm{mol} \mathrm{kg}^{-1}$ relative to the deeper Arctic in our gridded data set. By contrast, Jones et al. (2008) estimate a $\sim 5 \%$ average riverine end-member contribution to the shallowest $100 \mathrm{~m}$ of this region, which accounts for $\sim 55 \mu \mathrm{mol} \mathrm{kg}^{-1} \mathrm{Alk}^{*}$ enrichment. Also, surface Alk* in the Southern Ocean - which has sea ice but lacks major rivers - is not similarly elevated relative to surface phosphate (Fig. 2) or deep Alk* (Fig. 3).

\section{Controls on the calcite saturation state}

The Alk* tracer provides an opportunity to estimate the impact of carbonate cycling on $\Omega_{C}$. In addition to (1) carbonate cycling, $\Omega_{\mathrm{C}}$ is affected by (2) organic matter cycling, (3) freshwater cycling, (4) pressure changes on seawater, (5) heating and cooling, and (6) $A_{\mathrm{T}}$ changes from nitrogen fixation and denitrification. For each of these six processes, we estimate the standard deviation of the net influence of the process globally by considering the standard deviation of a "reference" tracer $R_{i}$ for the process, " $\sigma_{R_{i}}$ ", where $R_{i}$ is $\mathrm{Alk}^{*}$ for $\mathrm{CaCO}_{3}$ cycling, phosphate for organic matter cycling, salinity for freshwater cycling, pressure for pressure changes, temperature for heating and cooling, and $N^{*}$ (Gruber and Sarmiento, 1997) for nitrogen fixation and denitrifi- cation. We use the standard deviation of the reference tracer as a measure of the oceanic range of the net influence of the corresponding process. We measure the impact of this range on $\Omega_{\mathrm{C}}$ using a metric $M$, which we define as

$M_{i}=\sigma_{R_{i}}\left|S_{R_{i}}\right|$

where $S_{R_{i}}$ is the $\Omega_{\mathrm{C}}$ sensitivity to a unit process change in $R_{i}$, which we estimate in Appendix A. We are interested in the relative importance $I$ of our six processes, so we also calculate the percentage that each metric value estimate contributes to the sum of all six metric value estimates:

$I_{i}=100 \% \times \frac{M_{i}}{\sum_{i=1}^{6} M_{i}}$.

We derive and estimate our metric and its uncertainty in Appendix A. We carry out our analysis for the full water column assuming it to be isolated from the atmosphere (Sect. 4.1), and also for just the top $50 \mathrm{~m}$ of the water column assuming it to be well-equilibrated with the atmosphere (Sect. 4.2). Finally, we consider how equilibration with an atmosphere with a changing $p \mathrm{CO}_{2}$ alters surface $\Omega_{\mathrm{C}}$.

\subsection{Process importance in atmospherically isolated mean seawater from all ocean depths}

Our metric $M_{i}$ is an estimate of the standard deviation of the global distribution of $\Omega_{\mathrm{C}}$ resulting from the $i$ th process. Our relative process importance metric $I_{i}$ is an estimate of the percentage of overall variability of the $\Omega_{\mathrm{C}}$ distribution that can be attributed to that process. We provide $M$ and $I$ values for mean seawater from the full water column alongside the $R_{i}, S_{R_{i}}$, and $\sigma_{R_{i}}$ values used to estimate them in Table 1 . These calculations assume that the seawater is isolated from the atmosphere.

Relative process importance estimates $I$ indicate organic matter cycling ( $48 \%$ ) is the dominant process controlling $\Omega_{\mathrm{C}}$ for mean seawater. Changing pressure $(28 \%)$ is the secondmost-important process, followed by calcium carbonate cycling $(17 \%)$, temperature changes $(4 \%)$, nitrogen fixation and denitrification $(1.21 \%)$, and freshwater cycling $(0.78 \%)$.

\subsection{Process importance in well-equilibrated surface seawater}

In Table 2 we provide $M_{i}$ values for well-equilibrated seawater in the top $50 \mathrm{~m}$ of the ocean alongside the $R_{i}, \sigma_{R_{i}}$, and $S_{R_{i}}$ used to estimate them. These surface seawater $M_{i}$ values are calculated assuming the water remains equilibrated with an atmosphere with $400 \mu \mathrm{atm} p \mathrm{CO}_{2}$. We test the validity of this assumption by also estimating $M$ for the observed global $p \mathrm{CO}_{2}$ variability in the Takahashi et al. (2009) global data product. This test reveals transient air-sea disequilibria are indeed important for surface ocean $\Omega_{\mathrm{C}}$, but only as a 
Table 1. Metric estimates $M_{i}$, relative process importance percentages $I_{i}$, calcite saturation sensitivities $S_{R_{i}}$ to unit changes in the $R_{i}$ reference properties, and reference property standard deviations $\sigma_{R_{i}}$ for the $i=6$ processes in atmospherically isolated mean seawater from all ocean depths. We provide details on how these terms are estimated and $M_{i}$ and $I_{i}$ uncertainties are obtained.

\begin{tabular}{lllllll}
\hline Process & $i$ & $R_{i}$ & $S_{R_{i}}$ & $\sigma_{R_{i}}$ & $M_{i}$ & $I_{i}$ \\
\hline Carbonate cycling & 1 & Alk* & 0.0043 & $53.5 \mu \mathrm{mol} \mathrm{kg}^{-1}$ & 0.23 & $17 \%$ \\
Org. matter cycling & 2 & Phosphate & -0.0069 & $0.60 \mu \mathrm{mol} \mathrm{kg}-1$ & 0.66 & $48 \%$ \\
Freshwater cycling & 3 & Salinity & 0.032 & 0.27 & 0.011 & $0.78 \%$ \\
Sinking/shoaling & 4 & Pressure & -0.00028 & $1411 \mathrm{db}$ & 0.4 & $28 \%$ \\
Warming/cooling & 5 & Temp. & 0.014 & $4.20^{\circ} \mathrm{C}$ & 0.06 & $4 \%$ \\
Denit./nit. fix. & 6 & $N^{*}$ & -0.010 & $1.6 \mu \mathrm{mol} \mathrm{kg}-1$ & 0.017 & $1.2 \%$ \\
\hline
\end{tabular}

Table 2. Metric estimates $M_{i}$, relative process importance percentages $I_{i}$, calcite saturation sensitivities $S_{R_{i}}$ to unit changes in the $R_{i}$ reference properties, and reference property standard deviations $\sigma_{I_{i}}$ for the $i=6$ processes in well-equilibrated surface seawater. We provide details on how these terms are estimated and $M_{i}$ and $I_{i}$ uncertainties are obtained.

\begin{tabular}{lllllll}
\hline Process & $i$ & $R_{i}$ & $S_{R_{i}}$ & $\sigma_{R_{i}}$ & $M_{i}$ & $I_{i}$ \\
\hline Carbonate cycling & 1 & Alk* & 0.0034 & $36.9 \mu \mathrm{mol} \mathrm{kg}^{-1}$ & 0.13 & $7.8 \%$ \\
Org. matter cycling & 2 & Phosphate & -0.0045 & $0.51 \mu \mathrm{mol} \mathrm{kg}-1$ & 0.037 & $2.3 \%$ \\
Freshwater cycling & 3 & Salinity & 0.20 & 0.86 & 0.22 & $13.2 \%$ \\
Sinking/shoaling & 4 & Pressure & -0.00083 & $15 \mathrm{db}$ & 0.011 & $0.70 \%$ \\
Warming/cooling & 5 & Temp. & 0.14 & $8.8^{\circ} \mathrm{C}$ & 1.2 & $76 \%$ \\
Denit./nit. fix. & 6 & $N^{*}$ & -0.0043 & $1.5 \mu \mathrm{mol} \mathrm{kg}^{-1}$ & 0.006 & $0.40 \%$ \\
$p \mathrm{CO}_{2}$ disequilibria & $\mathrm{b}$ & $p \mathrm{CO}_{2}$ & -0.0086 & $27 \mu \mathrm{atm}^{\mathrm{a}}$ & 0.23 & $\mathrm{~b}$ \\
\hline
\end{tabular}

a standard deviation of the Takahashi et al. (2009) revised global monthly $p \mathrm{CO}_{2}$ climatology. ${ }^{\mathrm{b}}$ the $M$ value for disequilibria is only calculated to test our assumption of surface seawater air-sea equilibration and is omitted from calculations of $I_{i}$ for comparison with Table 1.

secondary factor when considered globally. Despite this, it is important to recognize that air-sea equilibration following a process is not instantaneous, and that the $S_{R_{i}}$ value estimates in Sect. 4.1 may be better for estimating short-term changes following fast-acting processes such as spring blooms (e.g., Tynan et al., 2014) or upwelling events (e.g., Feely et al., 1988). We omit the disequilibrium $M$ value estimate from the denominator of Eq. (7) to allow $I$ values for surface seawater to be compared to $I$ values from mean seawater globally.

Warming and cooling are the dominant processes controlling $\Omega_{\mathrm{C}}$ for well-equilibrated surface seawater (76\%). The large increase in $M$ for warming and cooling relative to the value calculated for mean seawater is due to lower equilibrium $C_{\mathrm{T}}$ at higher temperatures. Freshwater cycling is the second-most-important process $(13 \%)$, followed by carbonate cycling $(8 \%)$, organic matter cycling $(2 \%)$, pressure changes $(1 \%)$, and denitrification and nitrogen fixation $(0.4 \%)$. The increased importance of freshwater cycling compared to Sect. 4.1 is because freshwater dilutes $C_{\mathrm{T}}$ by more than the equilibrium $C_{\mathrm{T}}$ decreases from $A_{\mathrm{T}}$ dilution, so carbon uptake tends to follow freshwater precipitation and carbon outgassing follows evaporation. Carbonate cycling is less important because $A_{\mathrm{T}}$ decreases with carbonate precipitation lead to lower $C_{\mathrm{T}}$ at equilibrium. Organic matter cycling is much less important because atmospheric re- equilibration mostly negates the large changes in $C_{\mathrm{T}}$. Pressure changes are negligible because we only consider water in the surface $50 \mathrm{~m}$. Our air-sea disequilibrium $M$ estimate suggests surface disequilibria are comparably important to freshwater cycling for surface $\Omega_{\mathrm{C}}$ but substantially less important than temperature changes (this would correspond to an $I$ value of $\sim 14 \%$ ).

The dominance of warming and cooling and freshwater cycling over carbonate cycling is most evident in the Red Sea where high temperatures $\left(>25^{\circ} \mathrm{C}\right)$ and high salinities $(>40)$ lead to surface $\Omega_{\mathrm{C}}$ exceeding 6 despite extremely low Alk* $\left(<-200 \mu \mathrm{mol} \mathrm{kg}{ }^{-1}\right)$. The deep Red Sea is also unusual for having deep water that was warm when it last left contact with the atmosphere (the Red Sea is $>20^{\circ} \mathrm{C}$ at $>1000 \mathrm{~m}$ depth). This provides high initial deep $\Omega_{\mathrm{C}}$ that - combined with decreased influence of pressure changes at higher temperatures - keeps deep Red Sea $\Omega_{\mathrm{C}}>3$. Similarly, the lowest surface $\Omega_{\mathrm{C}}$ values are in the Arctic where there are low temperatures, low salinity, and high Alk* values from riverine inputs. The importance of warming and cooling is also suggested by the correlation between $\Omega_{\mathrm{C}}$ and the surface temperature $\left(R^{2}=0.96\right)$. These properties are plotted in Fig. 8 . 
a. Surface Calcite Saturation

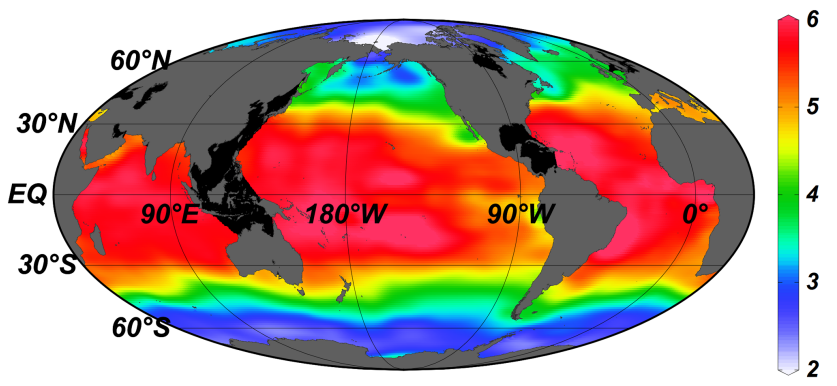

b. Surface Temperature $\left[{ }^{\circ} \mathrm{C}\right]$

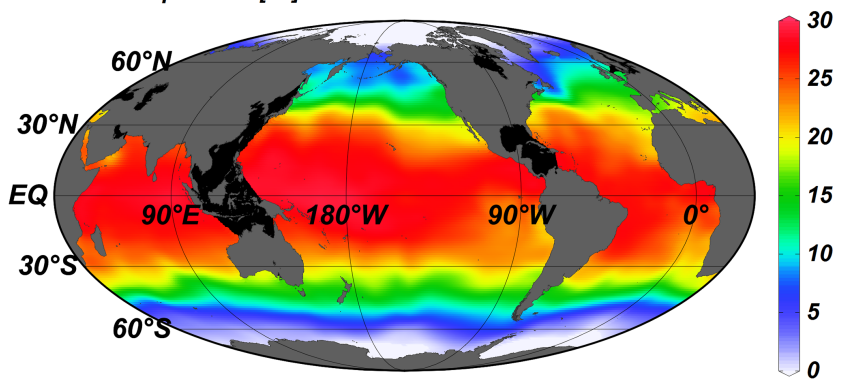

Figure 8. Gridded global (a) calcite saturation state $\Omega_{\mathrm{C}}$ and (b) temperature at the surface (10 m depth surface) of our gridded CARINA, PACIFICA, and GLODAP bottle data products. Areas with exceptionally poor coverage in the data used to produce the gridded product are blacked out.

\section{Conclusions}

Alk* isolates the portion of the $A_{\mathrm{T}}$ signal that varies in response to calcium carbonate cycling and exchanges with terrestrial and sedimentary environments from the portion that varies in response to freshwater and organic matter cycling. The salinity normalization we use has the advantage over previous salinity normalizations that it allows our tracer to mix linearly and to change in a $2: 1$ ratio with $C_{\mathrm{T}}$ in response to carbonate cycling. We highlight the following insights from Alk*:

1. Alk* distribution: the Alk* distribution clearly shows the influence of biological cycling, including such features as the very low Alk* in the Red Sea due to the high calcium carbonate precipitation there. We also find evidence of strong riverine $A_{\mathrm{T}}$ sources in the Bay of Bengal and in the Arctic. We show river inputs likely dominate over the small influences of ikaite cycling on the Arctic alkalinity distribution.

2. Influence of calcium carbonate cycling on marine calcite saturation state: Alk* allows us to quantify the net influence of calcium carbonate cycling on marine $\Omega_{\mathrm{C}}$. For well-equilibrated surface waters, carbonate cycling is less influential for $\Omega_{\mathrm{C}}$ than gas exchange driven by warming and cooling and freshwater cycling. At depth, the carbonate cycling signal is smaller than the signal from organic matter cycling and from pressure changes. Temperature is the dominant control on $\Omega_{\mathrm{C}}$ of surface waters in equilibrium with the atmosphere. This accounts for the low calcite saturation states in the cold surface of the Arctic and Southern oceans despite high regional Alk*, and high $\Omega_{\mathrm{C}}$ in the warm subtropics despite low regional Alk*.

We intend to use Alk* for two future projects. First, Alk* is superior to $A_{\mathrm{T}}$ for monitoring and modeling changes in marine chemistry resulting from changes in carbonate cycling with ocean acidification. $A_{\mathrm{T}}$ varies substantially in response to freshwater cycling, so Alk* trends may be able to be detected sooner and more confidently attributed to changes in calcium carbonate cycling than trends in $A_{\mathrm{T}}$ (Ilyina et al., 2009). Secondly, we will estimate global steady-state Alk* distributions using $\mathrm{Alk}^{*}$ sources and sinks from varied biogeochemical ocean circulation models alongside independent water mixing and transport estimates (e.g., Khatiwala et al., 2005; Khatiwala, 2007). We will interpret findings in the context of two hypotheses proposed to explain evidence for calcium carbonate dissolution above the aragonite saturation horizon: (1) that organic matter remineralization creates undersaturated microenvironments that promote carbonate dissolution in portions of the water column which are chemically supersaturated in bulk, and (2) that high-magnesium calcite and other impure minerals allow chemical dissolution above the saturation horizon. 
Appendix A: Definition of the process importance metric $M$

In simplest terms, our metric is the product of the $\Omega_{\mathrm{C}}$ sensitivity to a process and the variability of the net influence of the process globally. The difficulty in this calculation lies in quantifying the "net influence of a process." We first show how we change coordinates so we can use reference tracers as a proxy measurement for these net influences.

Our metric for $\Omega_{\mathrm{C}}$ variability resulting from the $i$ th process is expressed as $M_{i}$ :

$M_{i}=\sigma_{P_{i}}\left|\frac{\partial \Omega_{\mathrm{C}}}{\partial P_{i}}\right|$,

where $P_{i}$ is an abstract variable representing the net process influence (that we will later factor out), and $\frac{\partial \Omega_{\mathrm{C}}}{\partial P_{i}}$ is the $\Omega_{\mathrm{C}}$ sensitivity to the process. We expand $\frac{\partial \Omega_{\mathrm{C}}}{\partial P_{i}}$ using the chain rule to include a term for $\Omega_{\mathrm{C}}$ sensitivity to changes in the reference tracer $R_{i}$ (see Sect. 4) and a term $\frac{\partial R_{i}}{\partial P_{i}}$ representing changes in $R_{i}$ resulting from the $i$ th process:

$\frac{\partial \Omega_{\mathrm{C}}}{\partial P_{i}}=\frac{\partial \Omega_{\mathrm{C}}}{\partial R_{i}} \frac{\partial R_{i}}{\partial P_{i}}$.

In practice, we calculate $\Omega_{\mathrm{C}}$ as a function of $j=7$ properties: (1) pressure, (2) temperature, (3) salinity, (4) phosphate, (5) silicate, (6) $A_{\mathrm{T}}$, and (7) $C_{\mathrm{T}}$ for mean seawater and $p \mathrm{CO}_{2}$ for surface seawater, so we use the chain rule again to expand the $\frac{\partial \Omega_{\mathrm{C}}}{\partial R_{i}}$ terms as follows:

$\frac{\partial \Omega_{\mathrm{C}}}{\partial R_{i}}=\sum_{j=1}^{7} \frac{\partial \Omega_{\mathrm{C}}}{\partial X_{j}} \frac{\partial X_{j, i}}{\partial R_{i}}$.

Here, the $\frac{\partial X_{j, i}}{\partial R_{i}}$ are assumed terms (assumptions detailed shortly) that relate the effect of the $i$ th process on the $j$ th property to the effect of the process on $R_{i}$, and the $\frac{\partial \Omega}{\partial X_{j}}$ terms reflect $\Omega_{\mathrm{C}}$ sensitivity to changes in the $j$ properties used to calculate it.

We make assumptions regarding the $\frac{\partial X_{j, i}}{\partial X_{\mathrm{R}}}$ terms: we relate changes in temperature from sinking or shoaling to changes in pressure using the potential temperature $(\theta)$ routines of Fofonoff and Millard (1983); we assume freshwater cycling linearly concentrates $A_{\mathrm{T}}, C_{\mathrm{T}}$, phosphate, and silicate by the same ratio that it changes salinity; we relate $C_{\mathrm{T}}$, phosphate, and $A_{\mathrm{T}}$ changes from organic matter formation to changes in phosphate using the remineralization ratios found by Anderson and Sarmiento (1994) and the empirical relationship of Kanamori and Ikegami (1982); we also use Kanamori and Ikegami's (1982) constant to relate changes in $A_{\mathrm{T}}$ from nitrogen fixation and denitrification to changes in $\mathrm{N}^{*}$ from these processes; and we assume that an increase in $A_{\mathrm{T}}$ from calcium carbonate dissolution equals the Alk* increase, and that the corresponding increase in $C_{\mathrm{T}}$ equals half of this Alk* increase. We neglect any changes in $C_{\mathrm{T}}$ from denitrification and nitrogen fixation because these changes are better thought of as organic matter cycling occurring alongside nitrogen cycling.

We estimate $\frac{\partial \Omega}{\partial X_{j}}$ property sensitivity terms as the differences between $\Omega_{\mathrm{C}}$ calculated before and after augmenting $j$ th property by one unit. $\Omega_{\mathrm{C}}$ is calculated with the MATLAB CO2SYS routines written by van Heuven et al. (2009) using the carbonate system equilibrium constants of Mehrbach et al. (1973), as refit by Dickson and Millero (1987). Seawater $p \mathrm{CO}_{2}$ is used in place of $C_{\mathrm{T}}$ for the surface seawater calculations (when $j=7$ ) to calculate the change in $\Omega_{\mathrm{C}}$ that remains after the surface seawater is allowed to equilibrate with the atmosphere.

We assume that the distributions of our $R_{i}$ reference properties are linearly related to the $P_{i}$ net activities of their associated processes. This assumption implies

$\sigma_{P_{i}}=\sigma_{R_{i}}\left|\frac{\partial P_{i}}{\partial R_{i}}\right|$.

We can then substitute Eq. (A3) into Eq. (A2), and substitute this combined equation for $\frac{\partial \Omega_{\mathrm{C}}}{\partial P_{i}}$ and Eq. (A4) into Eq. (A1). We then cancel the $\frac{\partial P_{i}}{\partial R_{i}}$ and $\frac{\partial R_{i}}{\partial P_{i}}$ terms to obtain

$M_{i}=\sigma_{R_{i}}\left|\sum_{j=1}^{7} \frac{\partial \Omega_{\mathrm{C}}}{\partial X_{j}} \frac{\partial X_{j, i}}{\partial R_{i}}\right|$.

We then define $\Omega_{\mathrm{C}}$ sensitivity $S_{R_{i}}$ as

$S_{R_{i}}=\left|\sum_{j=1}^{7} \frac{\partial \Omega_{\mathrm{C}}}{\partial X_{j}} \frac{\partial X_{j, i}}{\partial R_{i}}\right|$,

where $S_{R_{i}}$ is the $\Omega_{\mathrm{C}}$ sensitivity to a change in the $i$ th process scaled to a unit change in the reference variable for that process. We can then substitute Eq. (A6) into Eq. (A5) to obtain Eq. (6). We use Eq. (A6) to define $S_{R_{i}}$ and Eq. (6) to calculate $M$. We provide the $\frac{\partial \Omega_{\mathrm{C}}}{\partial X_{j}}$ and $\frac{\partial X_{j, i}}{\partial R_{i}}$ values we use to estimate $S_{R_{i}}$ for atmospherically isolated seawater from all depths in Table A1 and for well-equilibrated surface seawater in Table A3. We perform a sample $I$ and $M$ calculation in Supplement document SE.

We use a Monte Carlo analysis to estimate variability and uncertainty in our metric $M$ and our percent relative process importance $I$ calculations. We calculate the standard deviations, $\sigma_{M}$ and $\sigma_{I}$, of pools of $1000 \mathrm{M}$ and $I$ estimates calculated after adjusting the seawater properties $X_{i}$ with a normally distributed perturbation with a standard deviation equal to the property standard deviation from the gridded data set. We find $\frac{\sigma_{I}}{I}$ is typically much smaller than $\frac{\sigma_{M}}{M}$. This is because $\Omega_{\mathrm{C}}$ sensitivity is typically proportional to the $\Omega_{\mathrm{C}}$ itself, so individual Monte Carlo $M$ estimates vary with the initial $\Omega_{\mathrm{C}}$ and one another. Our $\sigma_{M}$ estimates are therefore better thought of as measures of the ranges of sensitivities found in the modern ocean, while $\sigma_{I}$ represent variability in the relative importance of processes. We provide $\sigma_{M}$ and $\sigma_{I}$ for atmospherically isolated seawater globally in Table A2, and for well-equilibrated surface seawater in Table A4. 
Table A1. $\frac{\partial \Omega_{\mathrm{C}}}{\partial X_{j}}$ (bold text) and $\frac{\partial X_{j, i}}{\partial R_{i}}$ (italic text) terms used in Eq. (A5) for atmospherically isolated mean seawater from all ocean depths. These terms are specific to the $j=7$ (columns) properties we use to calculate $\Omega_{\mathrm{C}}$ and $i=6$ (rows) processes we consider. Units for $\frac{\partial \Omega_{\mathrm{C}}}{\partial X_{j}}$ are the inverse of the listed $X_{j}$ units. Units for $\frac{\partial X_{j, i}}{\partial R_{i}}$ are the $X_{j}$ units divided by the $R_{i}$ units given in Table 1 .

\begin{tabular}{|c|c|c|c|c|c|c|c|c|}
\hline \multirow{4}{*}{\multicolumn{2}{|c|}{$\begin{array}{l}\text { Properties } \\
\text { Units } \\
j \\
\text { Mean seawater values } \\
\frac{\partial \Omega_{\mathrm{C}}}{\partial X_{j}}\end{array}$}} & $\begin{array}{c}\text { Pressure } \\
\mathrm{db}\end{array}$ & $\begin{array}{c}\text { Temp } \\
{ }^{\circ} \mathrm{C}\end{array}$ & Salinity & $\begin{array}{c}\text { Phos. } \\
\mu_{\mathrm{mol} \mathrm{kg}}^{-1}\end{array}$ & $\begin{array}{c}\text { Silicate } \\
\mu \mathrm{mol} \mathrm{kg}\end{array}$ & $\begin{array}{c}A_{\mathrm{T}} \\
\mu \mathrm{mol} \mathrm{kg}\end{array}$ & $\begin{array}{c}C_{\mathrm{T}} \\
\mu \mathrm{mol} \mathrm{kg}\end{array}$ \\
\hline & & 1 & 2 & 3 & 4 & 5 & 6 & 7 \\
\hline & & 2235 & 3.7 & 34.71 & 2.15 & 49.0 & 2362 & 2254 \\
\hline & & -0.00028 & 0.014 & -0.011 & -0.0085 & -0.00012 & 0.0082 & -0.0079 \\
\hline Process & $i$ & $\frac{\partial X_{1, i}}{\partial R_{i}}$ & $\frac{\partial X_{2, i}}{\partial R_{i}}$ & $\frac{\partial X_{3, i}}{\partial R_{i}}$ & $\frac{\partial X_{4, i}}{\partial R_{i}}$ & $\frac{\partial X_{5, i}}{\partial R_{i}}$ & $\frac{\partial X_{6, i}}{\partial R_{i}}$ & $\frac{\partial X_{7, i}}{\partial R_{i}}$ \\
\hline Carbonate cycling & 1 & - & - & - & - & - & 1 & 0.5 \\
\hline Org. matter cycling & 2 & - & - & - & 1 & - & -20.16 & 117 \\
\hline Freshwater cycling & 3 & - & - & 1 & 0.062 & 1.4 & 68 & 65 \\
\hline Sinking/shoaling & 4 & 1 & 0.00010 & - & - & - & - & - \\
\hline Warming/cooling & 5 & - & 1 & - & - & - & - & - \\
\hline Denit./nit. fix. & 6 & - & - & - & - & - & -1.26 & - \\
\hline
\end{tabular}

Table A2. Monte Carlo-derived estimates for $M_{i}$ variability $\left(\sigma_{M_{i}}\right)$ and $I_{i}$ variability $\left(\sigma_{I_{i}}\right)$ for atmospherically isolated mean seawater from all ocean depths.

\begin{tabular}{lrrr}
\hline Process & $i$ & $\sigma_{M_{i}}$ & $\sigma_{I_{i}}$ \\
\hline Carbonate cycling & 1 & 0.09 & $1 \%$ \\
Org. matter cycling & 2 & 0.2 & $3 \%$ \\
Freshwater cycling & 3 & 0.006 & $0.08 \%$ \\
Sinking/shoaling & 4 & 0.2 & $5 \%$ \\
Warming/cooling & 5 & 0.02 & $2 \%$ \\
Denit./nit. fix. & 6 & 0.006 & $0.1 \%$ \\
\hline
\end{tabular}

Table A3. $\frac{\partial \Omega_{\mathrm{C}}}{\partial X_{j}}$ (bold text) and $\frac{\partial X_{j, i}}{\partial R_{i}}$ (italic text) terms used in Eq. (A5) for well-equilibrated surface seawater. These terms are specific to the $j=7$ (columns) properties we use to calculate $\Omega_{\mathrm{C}}$ and $i=6$ (rows) processes we consider. Units for $\frac{\partial \Omega_{\mathrm{C}}}{\partial X_{j}}$ are the inverse of the listed $X_{j}$ units. Units for $\frac{\partial X_{j, i}}{\partial R_{i}}$ are the $X_{j}$ units divided by the $R_{i}$ units given in Table 2.

\begin{tabular}{|c|c|c|c|c|c|c|c|c|}
\hline $\begin{array}{l}\text { Properties } \\
\text { Units }\end{array}$ & & $\begin{array}{c}\text { Pressure } \\
\mathrm{db}\end{array}$ & $\begin{array}{c}\text { Temp } \\
{ }^{\circ} \mathrm{C}\end{array}$ & Salinity & $\begin{array}{c}\text { Phos. } \\
\mu \mathrm{mol} \mathrm{kg}-1\end{array}$ & $\begin{array}{c}\text { Silicate } \\
\mu \mathrm{mol} \mathrm{kg}-1\end{array}$ & $\begin{array}{c}A_{\mathrm{T}} \\
\mu \mathrm{mol} \mathrm{kg}-1\end{array}$ & $\begin{array}{l}p \mathrm{CO}_{2} \\
\mu \mathrm{atm}\end{array}$ \\
\hline$j$ & & 1 & 2 & 3 & 4 & 5 & 6 & 7 \\
\hline Mean seawater values & & 25 & 18.3 & 34.82 & 0.51 & 2.5 & 2305 & 350 \\
\hline$\frac{\partial \Omega_{\mathrm{C}}}{\partial X_{j}}$ & & -0.00084 & 0.14 & -0.022 & -0.0038 & -0.00013 & 0.0034 & -0.0086 \\
\hline Process & $i$ & $\frac{\partial X_{1, i}}{\partial R_{i}}$ & $\frac{\partial X_{2, i}}{\partial R_{i}}$ & $\frac{\partial X_{3, i}}{\partial R_{i}}$ & $\frac{\partial X_{4, i}}{\partial R_{i}}$ & $\frac{\partial X_{5, i}}{\partial R_{i}}$ & $\frac{\partial X_{6, i}}{\partial R_{i}}$ & $\frac{\partial X_{7, i}}{\partial R_{i}}$ \\
\hline Carbonate cycling & 1 & - & - & - & - & - & 1 & - \\
\hline Org. matter cycling & 2 & - & - & - & 1 & - & -20.16 & - \\
\hline Freshwater cycling & 3 & - & - & 1 & 0.015 & 0.072 & 65.9 & - \\
\hline Sinking/shoaling & 4 & 1 & 0.00010 & - & - & - & - & - \\
\hline Warming/cooling & 5 & - & 1 & - & - & - & - & - \\
\hline Denit./nit. fix. & 6 & - & - & - & - & - & -1.26 & - \\
\hline
\end{tabular}


Table A4. Monte Carlo-derived estimates for $M_{i}$ variability $\left(\sigma_{M_{i}}\right)$ and $I_{i}$ variability $\left(\sigma_{I_{i}}\right)$ for well-equilibrated surface seawater.

\begin{tabular}{llll}
\hline Process & $i$ & $\sigma_{M_{i}}$ & $\sigma_{I_{i}}$ \\
\hline Carbonate cycling & 1 & 0.03 & $0.8 \%$ \\
Org. matter cycling & 2 & 0.01 & $0.2 \%$ \\
Freshwater cycling & 3 & 0.04 & $0.5 \%$ \\
Sinking/shoaling & 4 & 0.001 & $0.03 \%$ \\
Warming/cooling & 5 & 0.2 & $1 \%$ \\
Denit./nit. fix & 6 & 0.002 & $0.04 \%$ \\
\hline$p \mathrm{CO}_{2}$ disequilibria & $\mathrm{a}$ & 0.05 & $\mathrm{a}$ \\
\hline
\end{tabular}

a disequilibria are included only as a test of our assumption of surface seawater air-sea equilibration, so these $M_{i}$ values are omitted from calculations of $I$. 


\section{The Supplement related to this article is available online at doi:10.5194/bg-11-7349-2014-supplement.}

Acknowledgements. We thank Eun Young Kwon for contributions to early versions of this research. We also thank the US National Science Foundation for research support (ANT-1040957), as well as the numerous scientists and crew that contributed to the data sets used in this study. R. Key was supported by CICS grant NA08OAR432052. We also thank Judith Hauck and three anonymous reviewers for their helpful and constructive reviews.

Edited by: J.-P. Gattuso

\section{References}

Almogi-Labin, A., Luz, B., and Duplessy, J.: Quaternary paleooceanography, pteropod preservation and stable-isotope record of the Red Sea, Palaeogeogr., Palaeoclimateol., Palaeoecol., 57, 195-211, 1986

Anderson, L. A. and Sarmiento, J. L.: Redfield ratios of remineralization determined by nutrient data analysis, Global Biogeochem. Cy., 8, 65-80, 1994.

Azetsu-Scott, K., Clarke, A., Falkner, K., Hamilton, J., Jones, E. P., Lee, C., Petrie, B., Prinsenberg, S., Starr, M., and Yeats, P.: Calcium carbonate saturation states in the waters of the Canadian Arctic Archipelago and the Labrador Sea, J. Geophys. Res. Oc., 115, C11, doi:10.1029/2009JC005917, 2010.

Beldowski, J., Löffler, A., Schneider, B., and Joensuu, L.: Distribution and biogeochemical control of total $\mathrm{CO}_{2}$ and total alkalinity in the Baltic Sea, J. Mar. Sys., 81, 252-259, 2010.

Berelson, W. M., Balch, W. M., Najjar, R., Feely, R. A., Sabine, C., and Lee, K.: Relating estimates of $\mathrm{CaCO}_{3}$ production, export, and dissolution in the water column to measurements of $\mathrm{CaCO}_{3}$ rain into sediment traps and dissolution on the sea floor: A revised global carbonate budget, Global Biogeochem. Cy., 21, GB1024, doi:10.1029/2006GB002803, 2007.

Boudreau, B. P.: Carbonate dissolution rates at the deep ocean floor, Geophys. Res. Lett., 40, 1-5, doi:10.1029/2012GL054231, 2013.

Brewer, P. G. and Dyrssen, D.: Chemical oceanography of the Persian Gulf, Prog. Oceanogr., 14, 41-55, 1985.

Brewer, P. G., Wong, G. T. F., Bacon, M. P., and Spencer, D. W.: An oceanic calcium problem?, Earth Planet. Sci. Lett., 26, 81-87, 1975.

Cai, W.-J., Guo, X., Chen, C. A., Dai, M., Zhang, L., Zhai, W., Lohrenz, S. E., Yin, K., Harrison, P. J., and Wang, Y.: A comparative overview of weathering intensity and $\mathrm{HCO}_{3}^{-}$flux in the world's major rivers with emphasis on the Changjiang, Huanghe, Zhujiang (Pearl) and Mississippi Rivers, Cont. Shelf Res., 28, 1538-1549, 2008.

Chen, C.-T. A.: Shelf-vs. dissolution-generated alkalinity above the chemical lysocline, Deep Sea Res. II, 49, 5365-5375, 2002.

Cooley, S. R., Coles, V. J., Subramaniam, A., and Yager, P. P.: Seasonal variations in the Amazon plume-related atmospheric carbon sink, Global Biogeo. Chem. Cy., 21, GB3014, doi:10.1029/2006GB002831, 2007.
Craig, H. and Turekian, K. K.: The GEOSECS program 1976-1979, Earth Planet. Sci. Lett., 49, 263-265, 1980.

Dai, A. and Trenberth, K. E.: Estimates of freshwater discharge from continents: latitudinal and seasonal variations, J. Hydrometeorol., 3, 660-687, 2002.

de Villiers, S.: Excess dissolved calcium in the ocean: a hydrothermal hypothesis, Earth and Plan. Sci. Lett., 164, 624-641, 1998.

Dickson, A. G.: An exact definition of total alkalinity and a procedure for the estimation of alkalinity and total inorganic carbon from titation data, Deep-Sea Res. Pt. A, 28, 609-623, 1981.

Dickson, A. G. and Millero, F. J.: A comparison of the equilibrium constants for the dissociation of carbonic acid in seawater media, Deep-Sea Res. Pt. A, 34, 1733-1743, 1987.

Dieckmann, G. S., Nehrke, G., Papadimitriou, S., Göttlicher, J., Steininger, R., Kennedy, H., Wolf-Gladrow, D., and Thomas, D. N.: Calcium carbonate as ikaite crystals in Antarctic sea ice, Geophys. Res. Lett., 35, LO8051, doi:10.1029/2008GL033540, 2008.

Feely, R. A., Byrne, R. H., Acker, J. G., Betzer, P. R., Chen, C. A., Gendron, J. F., and Lamb, M F.: Winter-summer variations of calcite and aragonite saturation in the northeast Pacific, Mar. Chem. 25, 3, 227-241, 1988.

Feely, R. A., Sabine, C. L., Lee, K., Millero, F. J., Lamb, M. F., Greeley, D., Bullister, J. L., Key, R. M., Peng, T. H., and Kozyr, A.: In situ calcium carbonate dissolution in the Pacific Ocean, Global Biogeochem. Cy., 16, 1144, doi:10.1029/2002GB001866, 2002.

Fofonof, N. P. and Millard, R. C.: Algorithms for computations of fundamental properties of seawater, UNESCO Technical Papers in Marine Science No. 44, 53 pp., 1983.

Gascard, J. C., Raisbeck, G., Sequeira, S., Yiou, F., and Mork, K. Correction to "The Norwegian Atlantic Current in the Lofoten basin inferred from hydrological and tracer data (I-129) and its interaction with the Norwegian Coastal Current", Geophys. Res. Lett., 31, 1, doi:10.1029/2003GL018303, 2004.

Gevirtz, J. L. and Friedman, G. M.: Deep-Sea carbonate sediments of the Red Sea and their implications on marine lithification, J. Sed. Petrol., 36, 143-151, 1966.

Gruber, N. and Sarmiento, J. L.: Global patterns of marine nitrogen fixation and denitrification, Global Biogeochem. Cy., 11, 235266, 1997.

Hales, B.: Respiration, dissolution, and the lysocline, Paleoceanogr., 18, 1099, doi:10.1029/2003PA000915, 2003.

Hales, B. and Emerson, S.: Calcite dissolution in sediments of the Ceara Rise: In situ measurements of porewater $\mathrm{O}_{2}, \mathrm{pH}$, and $\mathrm{CO}_{2}$ (aq), Geochim. Cosmochim. Ac., 61, 501-514, 1997.

Honjo, S., Manganini, S. J., Krishfield, R. A., and Francois, R.: Particulate organic carbon fluxes to the ocean interior and factors controlling the biological pump: A synthesis of global sediment trap programs since 1983, Prog. Oceanogr., 76, 217-285, 2008.

Ilyina, T., Zeebe, R. E., Maier-Reimer, E., and Heinze, C.: Early detection of ocean acidification effects on marine calcification, Global Biogeochem. Cy., 23, GB1008, doi:10.1029/2008GB003278, 2009.

Jiang, Z. P., Tyrrell, T., Hydes, D. J., Dai, M., and Hartman, S. E.: Variability of alkalinity and the alkalinity-salinity relationship in the tropical and subtropical surface ocean, Global Biogeochem. Cy., 28, 729-742, 2014. 
Jones, E. P., Anderson, L. G., Jutterström, S., Mintrop, L., and Swift, J. H.: Pacific freshwater, river water and sea ice meltwater across Arctic Ocean basins: Results from the 2005 Beringia Expedition, J. Geophys. Res. Oc., 113, C8, doi:10.1029/2007JC004124, 2008.

Kanamori, S. and Ikegami, H.: Calcium-alkalinity relationship in the North Pacific, J. Oceanogr., 38, 57-62, 1982.

Kaushal, S. S., Likens, G. E., Utz, R. M., Pace, M. L., Grese, M., and Yepsen, M.: Increased river alkalinization in the Eastern US, Envi. Sci. Tech., 47, 10302-10311, 2013.

Key, R. M., Kozyr, A., Sabine, C. L., Lee, K., Wanninkhof, R., Bullister, J. L., Feely, R. A., Millero, F. J., Mordy, C., and Peng, T. H.: A global ocean carbon climatology: Results from Global Data Analysis Project (GLODAP), Global Biogeochem. Cy., 18, GB4031, doi:10.1029/2004GB002247, 2004.

Key, R. M., Tanhua, T., Olsen, A., Hoppema, M., Jutterström, S., Schirnick, C., van Heuven, S., Lin, X., Wallace, D., and Mintrop, L.: The CARINA data synthesis project: Introduction and overview, Earth Sys. Sci. Data, 2, 579-624, 2009.

Khatiwala, S.: A computational framework for simulation of biogeochemical tracers in the ocean, Global Biogeochemical Cy., 21, GB3001, doi:10.1029/2007GB002923, 2007.

Khatiwala, S., Visbeck, M., and Cane, M. A.: Accelerated simulation of passive tracers in ocean circulation models, Oc. Modell., 9, 51-69, 2005.

Mehrbach, C., Culberson, C. H., Hawley, J. E., and Pytkowicz, R. M.: Measurement of the apparent dissociation constants of carbonic acid in seawater at atmospheric pressure, Limnol. Oceanogr., 18, 897-907, 1973.

Millero, F. J., Lee, K., and Roche, M.: Distribution of alkalinity in the surface waters of the major oceans, Mar. Chem., 60, 111-130, 1998.

Milliman, J. D., Ross, D. A., and Ku, T. A.: Precipitation and lithification of deep-sea carbonates in the Red Sea, J. Sed Res., 39, 724-736, 1969.

Moore, W. S.: The effect of submarine groundwater discharge on the ocean, Mar. Sci., 2, 59-88, 2010.

Moore, W. S., Sarmiento, J. L., and Key, R. M.: Tracing the Amazon component of surface Atlantic water using ${ }^{228} \mathrm{Ra}$, salinity, and silica, J. Geophys. Res., 91, 2574-2580, 1986.

Morse, J. W., Andersson, A. J., and Mackenzie, F. T.: Initial responses of carbonate-rich shelf sediments to rising atmospheric $\mathrm{pCO}_{2}$ and "ocean acidification": Role of high Mg-calcites, Geochim. Cosmochm. Acta., 70, 5814-5830, 2006.

Orr, J. C., Fabry, V. J., Aumont, O., Bopp, L., Doney, S. C., Feely, R. A., Gnanadesikan, A., Gruber, N., Ishida, A., Joos, F., Key, R. M., Lindsay, K., Maier-Reimer, E., Matear, R., Monfray, P., Mouchet, A., Najjar, R. G., Plattner, G., Rodgers, K. B., Sabine, C. L., Sarmiento, J. L., Schlitzer, R., Slater, R. D., Totterdell, I. J., Weirig, M., Yamanaka, Y., and Yool, A.: Anthropogenic ocean acidification over the twenty-first century and its impact on calcifying organisms, Nature, 437, 681-686, 2005.

Robbins, P. E.: Oceanic carbon transport carried by freshwater divergence: Are salinity normalizations useful?, J. Geophys. Res, 106, 30939-30, 2001.
Sarmiento, J. L., Dunne, J., Gnanadesikan, A., Key, R. M., Matsumoto, K., and Slater, R.: A new estimate of the $\mathrm{CaCO}_{3}$ to organic carbon export ratio, Global Biogeochem. Cy., 16, 1107, doi:10.1029/2002GB001919, 2002.

Sarmiento, J. L., Gruber, N., Brzezinski, M. A., and Dunne, J. P.: High-latitude controls of thermocline nutrients and low latitude biological productivity, Nature, 427, 56-60, 2004.

Silverman, J., Lazar, B., and Erez, J.: Effect of aragonite saturation, temperature, and nutrients on the community calcification rate of a coral reef, J. Geophys. Res., 112, CO05004, doi:10.1029/2006JC003770, 2007.

Suzuki, T., Ishii, M., Aoyama, M., Christian, J. R., Enyo, K., Kawano, T., Key, R. M., Kosugi, N., Kozyr, A., Miller, L. A., Murata, A., Nakano, T, Ono, T., Saino, T., Sasaki, K., Sasano, D., Takatani, Y., Wakita, M., and Sabine, C. L.: PACIFICA Data Synthesis Project, ORNL/CDIAC-159, NDP-092, Carbon Dioxide Information Analysis Center, Oak Ridge National Laboratory, US Department of Energy, Oak Ridge, Tennessee, 2013.

Takahashi, T., Sutherland, S. C., Wanninkhof, R., Sweeney, C., Feely, R. A., Chipman, D. W., Hales, B., Friederich, G., Chavez, F., Sabine C. L., Watson, A., Bakker D. C. E., Schuster, U., Metzl, N., Yoshikawa-Inoue H., Ishii, M., Midorikawa, T., Nojiri, Y., Körtzinger, A., Steinhoff, T., Hoppema, M., Olafsson, J., Arnarson, T. S., Tilbrook, B., Johannessen, T., Olsen, A., Bellerby, R., Wong, C. S., Delille, B., Bates, N. R., and deBarr, J. W.: Climatological mean and decadal change in surface ocean $\mathrm{pCO}_{2}$, and net sea-air $\mathrm{CO}_{2}$ flux over the global oceans, Deep Sea Res. II, 56, 554-577, 2009.

Thomas, H., Bozec, Y., De Baar, H. J., Elkalay, K., Frankignoulle, M., Schiettecatte, L. S., Kattner, G., and Borges, A. V.: The carbon budget of the North Sea, Biogeosciences, 2, 87-96, doi:10.5194/bg-2-87-2005, 2005.

Tynan, E., T. Tyrrell, and Achterberg, E. P.: Controls on the seasonal variability of calcium carbonate saturation states in the Atlantic gateway to the Arctic Ocean, Mar. Chem., 158, 1-9, 2014.

van Heuven, S., Pierrot, D., Lewis, E., and Wallace, D.: MATLAB Program developed for $\mathrm{CO}_{2}$ system calculations, ORNL/CDIAC-105b, Carbon Dioxide Information Analysis Center, Oak Ridge National Laboratory, US Department of Energy, Oak Ridge, Tennessee, 2009.

Velo, A., Perez, F. F., Brown, P., Tanhua, T., Schuster, U., and Key, R. M.: CARINA alkalinity data in the Atlantic Ocean, Earth Syst. Sci. Data, 1, 45-61, 2009, http://www.earth-syst-sci-data.net/1/45/2009/.

Wolery, T. J. and Sleep, N. H.: Interactions of geochemical cycles with the mantle, in: Chemical cycles in the evolution of the earth, edited by: Gregor, C. B., Garrels, R. M., Mackenzie, F. T., and Maynard, Wiley J. B., New York, 77-103, 1988.

Wolf-Gladrow, D. A., Zeebe, R. E., Klaas, C., Körtzinger, A., and Dickson, A. G.: Total alkalinity: The explicit conservative expression and its application to biogeochemical processes, Mar. Chem., 106, 287-300, 2007.

Yamamoto-Kawai, M., McLaughlin, F. A., Carmack, E. C., Nishino, S., and Shimada, K.: Aragonite undersaturation in the Arctic Ocean; effects of ocean acidification and sea ice melt, Science, 326, 1098, doi:10.1126/science.1174190, 2009. 